\title{
SISTEM PAKAR DIAGNOSA PENYAKIT GINJAL DAN SALURAN KEMIH DENGAN METODE BREADTH FIRST SEARCH
}

\author{
Yogi Aditya Pratama ${ }^{1}$, Erfian Junianto ${ }^{2}$ \\ ${ }^{1}$ Jurusan Sistem Informasi \\ AMIK BSI Bandung \\ Jalan Sekolah Internasional No.1-6 Antapani Bandung 40282 \\ yogi.aditya28@gmail.com \\ ${ }^{2}$ Fakultas Teknik \\ Universitas BSI Bandung \\ Jalan Sekolah Internasional No.1-6 Antapani Bandung 40282 \\ erfian.ejn@bsi.ac.id
}

\begin{abstract}
Currently kidney disease affects adult mortality throughout the world especially continent of Asia, Australia, Northern Europe, and South America. Kidney disease can be a strong indicator of risk of death and end-stage renal disease. The cause of kidney disease is affecting due to lack of knowledge about the information the symptoms that arise in kidney disease and also the lack of health services and facilities especially to the kidney disease itself. An expert system is a knowledge-based system program that provides a solution that can solve the problem as it is usually done by experts. Development of an expert system using Breadth First Search method, which has advantages such as not going to hit a dead end in the search process solution, if there is more than one solution, the minimum solution will be selected to perform diagnosis of kidney and urinary tract diseases. So with this expected applications can improve the performance of health services and facilities, as well as the patient can take further action without having to wait for a doctor's examination.
\end{abstract}

Keyword : Expert System, Kidney Disease, Urinary Tract, Breadth First Search Methode.

\begin{abstract}
Abstrak - Saat ini penyakit ginjal mempengaruhi kematian orang dewasa di seluruh Dunia khususnya Benua Asia, Australia, Eropa Utara, dan Amerika Selatan. Penyakit ginjal menjadi indikator kuat risiko kematian dan stadium akhir penyakit ginjal. Penyebab yang mempengaruhi penyakit ginjal ini dikarenakan kurangnya pengetahuan tentang informasi gejala-gejala yang timbul pada penyakit ginjal dan juga kurangnya pelayanan dan fasilitas kesehatan kususnya untuk penyakit ginjal itu sendiri. Sistem pakar merupakan sistem program berbasis pengetahuan yang menyediakan solusi yang dapat menyelesaikan masalah seperti yang biasa dilakukan oleh para ahli. Pengembangan sistem pakar menggunakan metode Breadth First Search, yang mempunyai kelebihan diantaranya tidak akan menemui jalan buntu dalam melakukan proses pencarian solusi, jika terdapat lebih dari satu solusi maka solusi minimum akan dipilih untuk melakukan diagnosa penyakit ginjal dan saluran kemih. Maka dengan ini diharapkan aplikasi ini dapat meningkatkan kinerja pelayanan dan fasilitas kesehatan, serta pasien dapat melakukan diagnosa awal untuk penyakit ginjal tanpa harus menunggu pemeriksaan dokter.
\end{abstract}

Kata Kunci : Sistem Pakar, Penyakit Ginjal, Saluran Kemih, Metode Breadth First Search. 


\section{PENDAHULUAN}

Gejala Penyakit Ginjal harus diketahui oleh setiap orang, karena memang penyakit ini sulit dideteksi (sering tidak ada tanda-tanda peringatan) namun sangat mengancam kehidupan seseorang. Dan kondisi terburuk pasien penyakit Ginjal adalah tidak berfunsinya ginjal dalam tubuh dalam periode bulan atau tahun. Penyakit ginjal saat ini mempengaruhi kematian sekitar $10 \%$ sampai $16 \%$ orang dewasa di seluruh Dunia Khususnya Benua Asia, Australia, Eropa Utara, dan Amerika Selatan. Hipertensi dan diabetes adalah kondisi umum yang disertai dengan penyakit ginjal menjadi penyebab kematian di berbagai belahan dunia tersebut. Hal tersebut didukung dari 46 penelitian yang dilakukan di John Hopkins Bloomberg School of Public Health (1972-2011) yang memfokuskan setelah menganalisa data sebanyak dua juta partisipan dari benua Asia, Australia, Eropa Utara, dan Amerika Selatan menemukan bahwa penyakit ginjal menjadi indikator kuat risiko kematian dan stadium akhir penyakit ginjal.

Penyebab yang mempengaruhi penyakit ginjal ini dikarenakan kurangnya pengetahuan tentang informasi gejala-gejala yang timbul pada penyakit ginjal dan juga kurangnya fasilitas kesehatan kususnya untuk penyakit ginjal itu sendiri. Sehingga dalam bidang kesehatan dibutuhkan juga sebuah teknologi komputer yang mampu mendiagnosa penyakit ginjal dan saluran kemih.

Sistem pakar merupakan sistem program berbasis pengetahuan yang menyediakan solusi yang dapat menyelesaikan masalah seperti yang biasa dilakukan oleh para ahli. Pembuatan sistem pakar bukan untuk menggantikan ahli itu sendiri melainkan dapat digunakan sebagai asisten yang sangat berpengalaman. Sistem pakar biasanya digunakan untuk mengimplementasi pada bidang kesehatan yaitu untuk melakukan diagnosa awal. Breadth First Search merupakan pencarian yang dilakukan dengan mengunjungi tiap-tiap node secara sistematis pada setiap level hingga keadaan tujuan (goal state) ditemukan atau hingga ditemukan goal state-nya.

\section{METODE PENELITIAN}

Metode pengembangan sistem yang digunakan oleh penulis pada penelitian ini adalah WaterFall atau sering disebut model sekuensial linier yang merupakan pendekatan pengembangan perangkat lunak yang sistematis dan sekuensial. Menurut Martin Fowler (2005:28) metode WaterFall adalah memecahkan sebuah proyek berdasarkan aktivitas. Untuk membuat perangkat lunak, anda harus melakukan tahapan-tahapan dalam penggunan metode WaterFall. Dan berikut ini tahapan yang penulis gunakan pada penelitian ini:

\section{Analisa Kebutuhan Software}

Karena kurangnya fasilitas kesehatan kususnya untuk penyakit ginjal dan saluran kemih dalam bidang kesehatan, maka dibutuhkan juga sebuah teknologi komputer yang mampu mendiagnosa penyakit ginjal dan saluran kemih ini. Oleh karena itu penulis memerlukan suatu interface program yang dapat memudahkan bagi pasien untuk mendapatkan informasi tentang gejala yang timbul sebagai penyebab dari penyakit ginjal dan saluran kemih. Dari uraian diatas penulis menentukan software yang sesuai dengan kriteria yang dibutuhkan dan yang akan digunakan sebagai proses komputerisasi sistem pakar diagnosa penyakit ginjal dan saluran kemih adalah VB.net

\section{Perancangan Sistem dan Perangkat Lunak \\ Desain VB.net tidak dapat dipisahkan} dengan sistem database yang berfungsi untuk menyimpan data-data pasien, gejala-gejala, penyakit dan nama dokter. Hal tersebut dimaksudkan agar proses penyimpanan akan berlangsung lebih aman. Selain itu, VB.net mempunyai tampilan (User Interface) yang dapat memudahkan pasien dalam proses mendapatkan informasi tentang gejala 
yang timbul sebagai penyebab dari penyakit ginjal dan saluran kemih.

\section{Implementasi dan Pengujian Unit}

Pengimplementasian sistem yang akan penulis buat ini bertujuan untuk memudahkan untuk mendapatkan informasi tentang gejala yang timbul sebagai penyebab dari penyakit ginjal dan saluran kemih, agar sesuai dengan perkembangan Teknologi Informasi dewasa ini. Dan untuk proses pengujian yang penulis lakukan terhadap program ini menggunakan sistem Blackbox Testing yang cenderung dapat menemukan hal-hal seperti fungsi yang tidak benar atau tidak ada, kesalahan antarmuka (interface errors), kesalahan pada struktur data dan akses basis data, kesalahan peformansi (performance errors), kesalahan inisialisasi dan terminasi.

\section{PEMBAHASAN}

\section{Sistem Pakar (Expert System)}

Sistem Pakar merupakan cabang dari kecerdasan buatan (Artificial Intelligence) dan juga merupakan bidang ilmu yang muncul seiring perkembangan ilmu komputer saat ini. "Sistem Pakar adalah sistem komputer yang bisa menyamai atau meniru kemampuan seorang pakar" Menurut Giarratano dan Riley dalam Desiani dan Arhami (2006:8). Sistem ini bekerja untuk mengadopsi pengetahuan manusia ke komputer yang menggabungkan dasar pengetahuan (knowledge base) dengan sistem inferensi untuk menggantikan fungsi seorang pakar dalam menyelesaikan suatu masalah. Sistem pakar sebagai kecerdasan buatan, menggabungkan pengetahuan dan faktafakta serta teknik penelusuran untuk memecahkan permasalahan yang secara normal memerlukan keahlian dari seorang pakar. Tujuan utama pengembangan sistem pakar ini adalah mensubstitusikan pengetahuan dan pengalaman pakar diberbagai bidang seperti bidang pertanian, bisnis, pendidikan, ilmu pengetahuan, komunikasi dan transportasi, kelautan dan bidang kesehatan.

\section{Struktur Sistem Pakar}

Menurut Turban dalam Desaini dan Arhami (2006:233) "Sistem pakar disusun oleh dua bagian utama, yaitu lingkungan pengembangan (development environment) dan lingkungan konsultasi (consultation environment)". Lingkungan pengembangan sistem pakar digunakan untuk memasukan pengetahuan pakar ke dalam lingkungan sistem pakar, sedangkan lingkungan konsultasi digunakan oleh pengguna yang bukan pakar dalam memperoleh pengetahuan pakar.

\section{Unsur Manusia dalma Sistem Pakar}

Menurut Turban dalam Desiani dan Arhami (2006:240) ada unsur manusia dalam sistem pakar yaitu:

1. Pakar (The Expert)

Pakar merupakan orang yang menguasai bidang ilmu pengetahuan tertentu, berpengalaman, pengambil keputusan dan menguasai metodemetode tertentu, serta mampu memanfaatkan kemampuannya dalam memberikan nasehat/saran terhadap penyelesaian suatu permasalahan.

2. Perekayasa Pengetahuan (Knowledge Engineer)

Orang yang membantu pakar dalam menyusun area permasalahan dengan menginterpretasikan dan mengintegrasikan jawaban-jawaban pakar atas pertanyaan yang diajukan, menggambarkan analogi, mengajukan counter example dan menerangkan kesulitan-kesulitan konseptual.

3. Pemakai (User)

Sistem pakar memiliki beberapa kelas pemakai, yaitu:

a. Pemakai bukan pakar, dalam hal ini sistem pakar berperan sebagai seorang konsulatan atau pemberi nasihat.

b. Siswa ingin belajar, disini sistem pakar berperan sebagai instruktur.

c. Pembangun sistem pakar yang ingin meningkatkan dan menabah basis pengetahuan, 
dalam hal ini sistem pakar berperan sebagai rekan kerja (Partner).

d. Pakar dalam hal ini sistem pakar berperan sebagai asisten.

4. Unsur lainnya

Beberapa unsur lainnya yang mungkin termasuk ke dalam usur manusia untuk sistem pakar adalah pembangun sistem (system builder) atau system analyst yang membantu mengintegrasikan sebuah sistem pakar dengan sistem terkomputerisasi lainnya.

\section{Metode Breadth First Search}

Metode Breadth First Search (BFS) merupakan pencarian yang dilakukan dengan mengunjungi tiap-tiap node secara sistematis pada setiap level hingga keadaan tujuan (goal state) ditemukan. Dengan kata lain menggunjungi terlebih dahulu semua node yang selevel hingga ditemukan goal statenya. Breadth First Search dapat diartikan juga dengan algoritma pencarian simpul dalam graf (pohon) secara travelsal yang dimulai dari simpul akar dan mengecek semua simpul-simpul tetangganya. Setelah itu, dari tiap simpul tetangganya, algoritma akan terus mencek semua simpul tetangganya yang belum dicek, sedemikian seterusnya hingga menemukan simpul tujuan Breadt First Search. Interpreter kaidah mulai dari fakta yang ada yaitu hipotesa kemudian kaidah bagian THEN mulai di uji untuk mendukung hipotesa awal. Jika ditemukan maka kaidah IF yang cocok digunakan untuk menghasilkan hipotesa antara yang baru. Kemudian proses berantai terus di ulang, mengumpulkan bukti yang mendukung, sehingga hipotesa terbukti kebenarannya. Keuntungan dari metode ini :

1. Tidak menemui jalan buntu.

2. Jika ada suatu solusi, maka Breadthfirst search akan menemukannya.

3. Jika didapat lebih dari satu solusi, maka solusi minimum akan ditemukan.
Kelemahan metode ini :

1. Membutuhkan memori yang cukup banyak, karena menyimpan semua node dalam suatu pohon.

2. Membutuhkan waktu yang cukup lama, karena akan menguji $n$ level untuk mendapatkan solusi pada level ke- $(n+1)$.

\section{Entity Relationship Diagram (ERD)}

Menurut pendapat Kronke (2006:3740) Entity-Relationship Diagram (ERD) adalah adalah suatu pemodelan konseptual yang didesain secara khusus untuk mengidentifikasikan entitas yang menjelaskan data dan hubungan antar data, yaitu dengan menuliskan dalam cardinality. Sementara seolah-olah teknik diagram atau alat peraga memberikan dasar untuk desain database relasional yang mendasari sistem informasi yang dikembangkan. ERD bersama-sama dengan detail pendukung merupakan model data yang pada gilirannya digunakan sebagai spesifikasi untuk database. Dalam sistem Entity Relationship Diagram (ERD), terdapat beberapa istilah penting diantaranya :

1. Entitas (Entity)

Suatu entitas yang dapat berupa orang, tempat, obyek, atau kejadian yang dianggap penting bagi perusahaan, sehingga segala atributnya harus dicatat dan disimpan dalam basis data.

2. Atribut (Atribute)

Setiap entitas mempunyai karakterisik tertentu yang dinamakan dengan atribut.

3. Relasi (relationship)

Hubungan antara dua atau lebih entitas yang saling berkaitan. Menurut Romney (2009:596) ada tiga tipe relasi (relationship), yaitu:

a. One-to-one relationship (1:1) Dimana maximum cardinality setiap entity adalah 1.

Contoh : Satu nasabah bank hanya memiliki satu account.

b. One-to-many relationship (1:N). Dimana maximum cardinality dari suatu entity adalah 1 dan maximum cardinality dari entity lain adalah $\mathrm{N}$. 
Contoh : Satu nasabah bank dapat memiliki lebih dari satu account.

c. Many-to-many relationship (M:N). Dimana maximum cardinality kedua entity yang berhubungan adalah $\mathrm{N}$.

Contoh : Satu nasabah dapat memilliki beberapa account dan satu account dapat dimiliki oleh beberapa nasabah (rekening bersama).

\section{Identifier}

Merupakan nama atribute yang digunakan untuk mengidentifikasi suatu entitas, Ada tiga jenis identifier diantaranya Primary Key, Secondary Key, dan Foreign Key.

Dalam penulisan tugas akhir ini hanya menggunakan Primary Key dan Foreign Key, berikut ini penjelasan dari Primary Key dan Foreign Key:

a. Primary Key merupakan suatu kode identifikasi yang bersifat unik yang ditunjukkan oleh masing-masing record dalam sistem. Tujuan dari Primary key adalah untuk menunjukkan lokasi tiap catatan di dalam suatu file mengenai catatan-catatan serupa.

b. Foreign Key merupakan attribute yang merupakan Primary key dari relasi lain yang ditarik/dihubungkan ke suatu relasi.

5. Kardinalitas (Cardinality)

Merupakan kendala-kendala yang timbul dalam hubungan antar entitas.

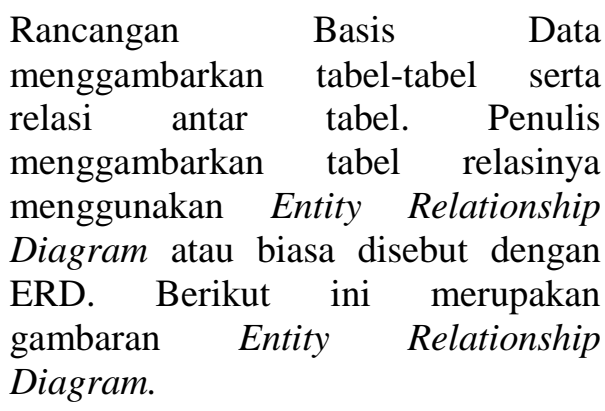

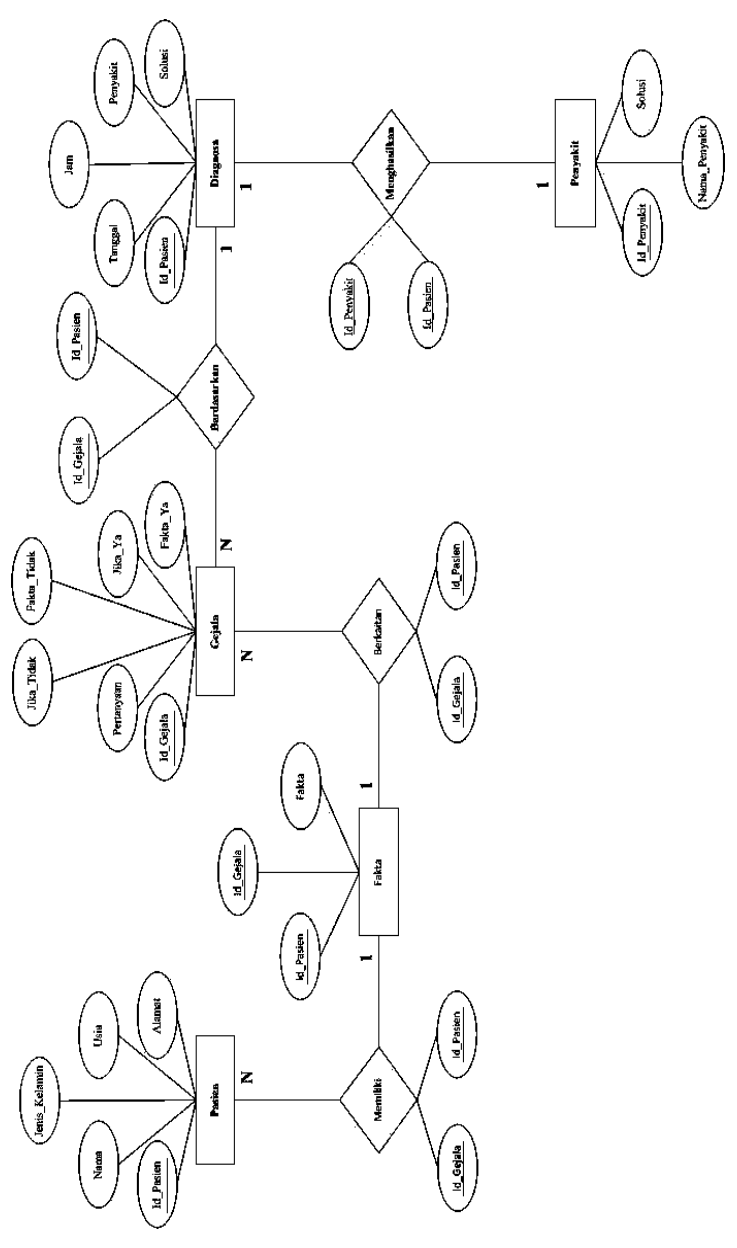

Gambar 2

Entity Relationship Diagram (ERD)

\section{Unified Modeling Language (UML)}

UML disebut sebagai bahasa pemodelan bukan metode. Kebanyakan metode terdiri paling sedikit prinsip, bahasa pemodelan dan proses. Bahasa pemodelan (sebagian besar grafik) merupakan notasi dari metode yang digunakan untuk mendesain secara cepat. Menurut Rosa dan Shalahuddin (2013:133) UML (Unified Modeling Language) adalah salah satu standar bahasa visual yang banyak digunakan di dunia industri untuk mengidentifikasi requirement, membuat analisis \& desain, serta menggambarkan arsitektur dalam pemrograman berorientasi objek. UML muncul karena adanya kebutuhan pemodelan visual untuk menspesifikasikan, menggambarkan, membangun, dan dokumentasi dari sistem perangkat lunak. UML hanya berfungsi untuk melakukan pemodelan, 
jadi penggunaan UML tidak terbatas pada metologi tertentu, meskipun pada kenyataannya UML paling banyak diguakan pada metodologi berorientasi objek. Diagram UML yang digunakan dalam penulisan tugas akhir ini adalah sebagai berikut:

\section{Use Case Diagram}

Use Case Diagram menurut Widodo (2011:10) Diagram use case bersifat statis, yang memperlihatkan himpunan Use Case dan aktor-aktor (suatu jenis khusus dari kelas) dan menggambarkan apa saja aktifitas yang dilakukan oleh suatu sistem dari sudut pandang pengamatan luar. Diagram ini terutama sangat penting untuk mengorganisasi dan memodelkan perilaku suatu sistem yang dibutuhkan serta diharapkan pengguna yang menjadi persoalan itu apa yang dilakukan bukan bagaimana melakukannya. Use Case Diagram menggambarkan fungsionalitas yang diharapkan dari sistem. Berikut ini merupakan Use Case Diagram yang menggambarkan aplikasi sistem diagnosa penyakit ginjal dan saluran kemih secara keseluruhan:

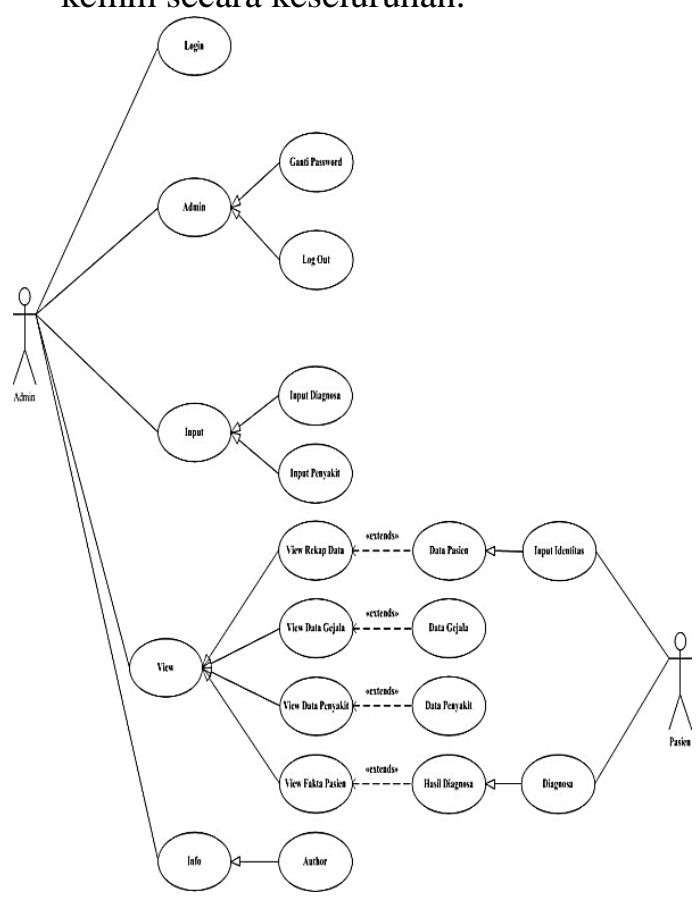

Gambar 2

Use Case Diagram

\section{Class Diagram}

Class Diagram menurut Munawar (2005:28) merupakan himpunan dari objek-objek yang sejenis. Sebuah objek memiliki keadaan sesaat (state) dan perilaku (behavior). State sebuah objek adalah kondisi objek tersebut yang dinyatakan dalam attribute. Sedangkan perilaku suatu objek mendefinisikan bagaimana sebuah objek bertindak dan memberikan. Rancangan Arsitektur Perangkat Lunak menggambarkan desain sistem dari sistem yang akan dibuat. Untuk menggambarkan arsitektur perangkat lunak dari sistem yang akan dibuat maka penulis menggunakan class diagram sebagai berikut (lihat Gambar 3):

\section{Squence Diagram}

Squence Diagram menurut Munawar (2005:187) adalah grafik dua dimensi dimana obyek ditujukan dalam dimensi horizontal, sedangkan lifeline ditunjukan dalam dimensi vertikal.

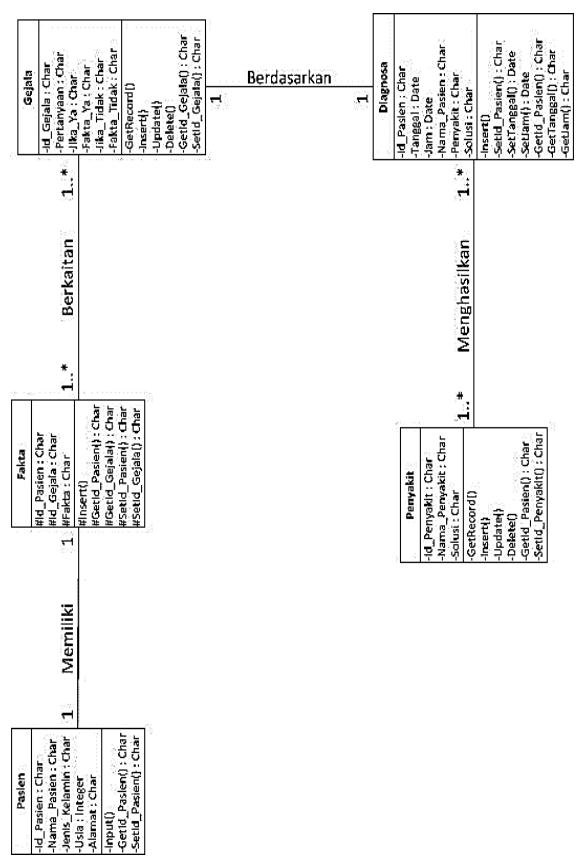

Gambar 3

Class Diagram 


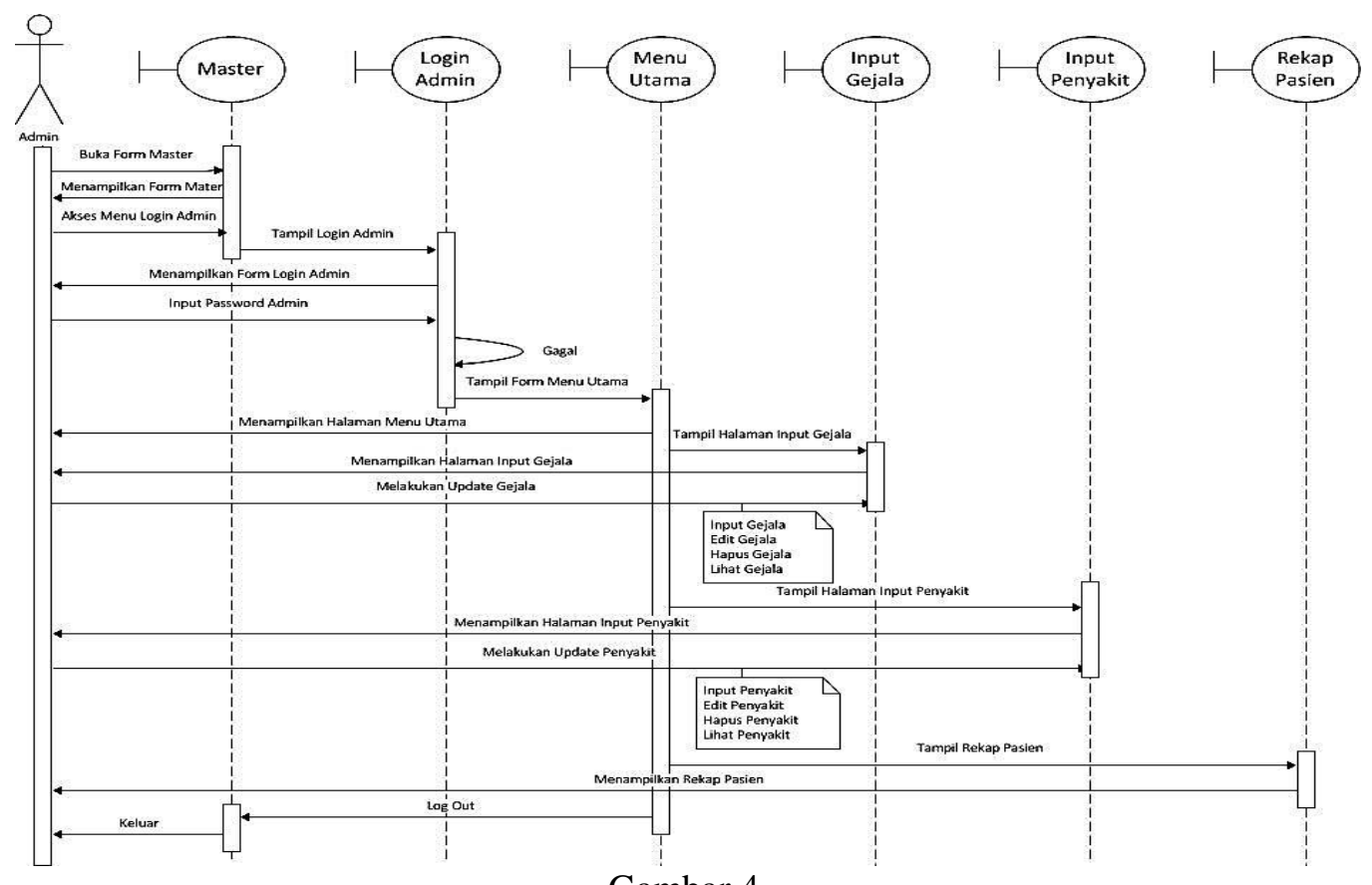

Gambar 4.

Sequence Diagram Admin

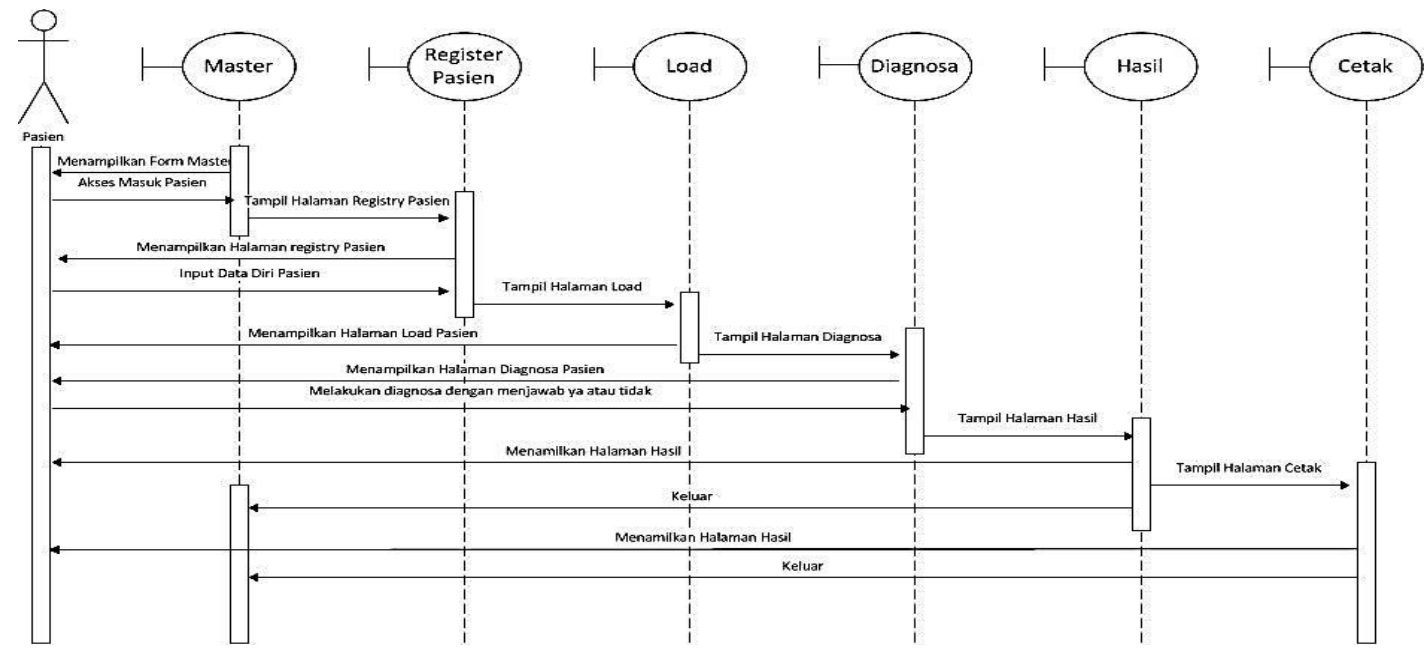

Gambar 5

Sequence Diagram Pasien

\section{Pengujian Blackbox}

Pengujian menggunakan
sekumpulan aktifitas validasi, dengan pendekatan black box testing. Menurut Shalahuddin dan Rosa (2011), black box testing adalah menguji perangkat lunak dari segi spesifikasi fungsional tanpa menguji desain dan kode program. Pengujian dimaksudkan untuk mengetahui apakah fungsi-fungsi, masukan, dan keluaran dari perangkat lunak sesuai dengan spesifikasi yang dibutuhkan. Pengujian kotak hitam dilakukan dengan membuat kasus uji yang bersifat mencoba semua fungsi dengan memakai perangkat lunak apakah sesuai dengan spesifikasi yang dibutuhkan. Kasus uji yang dibuat untuk melakukan pengujian black box testing harus dibuat dengan kasus benar dan kasus salah. 


\section{Implementasi}

1. Form Master

Disini adalah pemisah antara bagian dokter dengan pasien untuk melakukan diagnosa dan tampilan utama dari sistem pakar diagnosa penyakit ginjal dan saluran kemih.

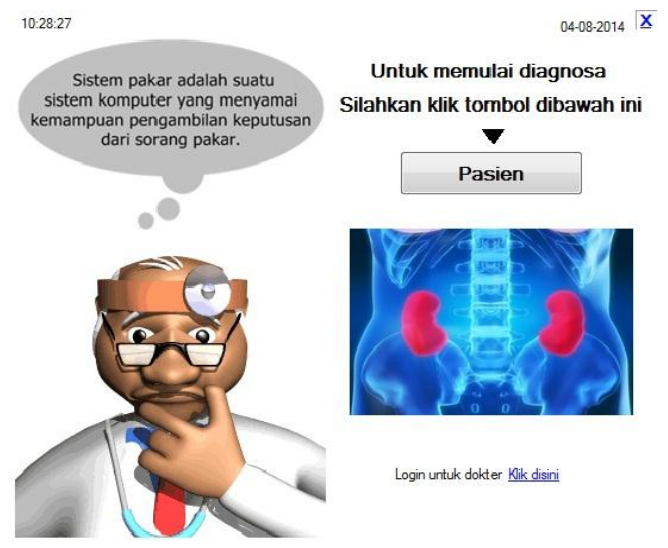

Gambar 6

Form Master

\section{Form Menu Utama}

Dokter dapat melakukan perubahan dari data diagnosa, penyakit, password, jadwal praktek dan dapat mencetak data-data yang sudah masuk ke dalam sistem ini.

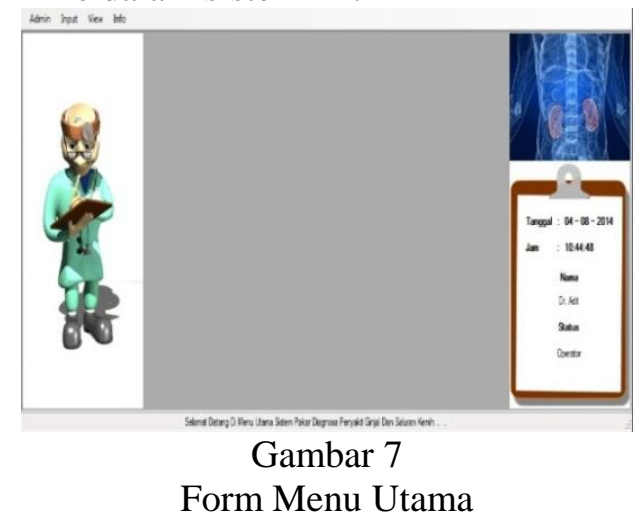

3. Form Input Gejala Penyakit Admin harus memasukan data untuk diagnosa yang dilakukan pasien.

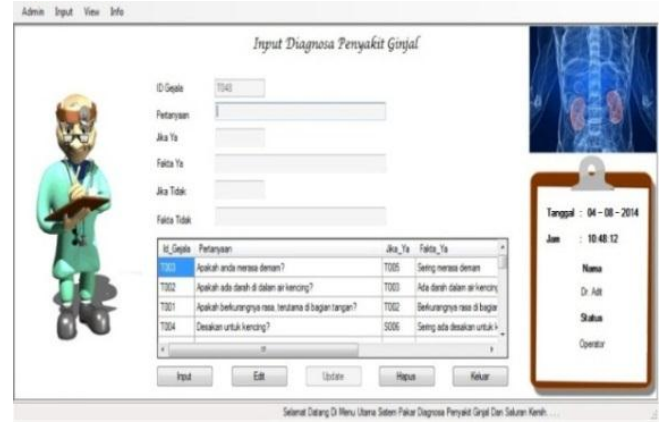

Gambar 8

Form Input Gejala Penyakit

4. Form Input Penyakit

Admin juga harus memasukan data penyakit untuk menentukan gejala apa yang di alami pasien setelah melakukan diagnosa yang dilakukan pasien.

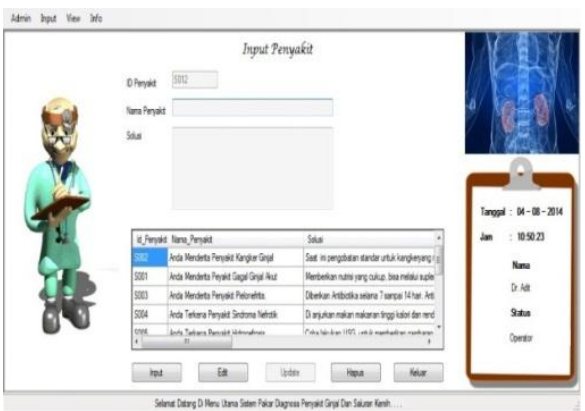

Gambar 9

Form Input Penyakit

5. From View Data Rekap Pasien

Disini dokter dapat melihat data pasien yang telah melakukan diagnosa di sistem pakar ini. Dan dokter juga dapat mencetak semua data pasien ke dalam bentuk dokumen.

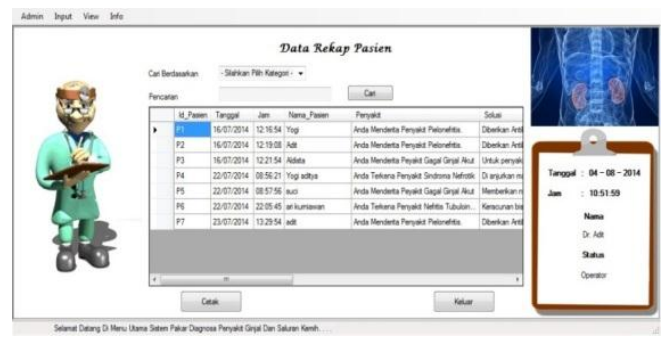

Gambar 10

Form View Data Rekap pasien 
6. Form Identitas Pasien

Pasien harus mengisi identitas diri sendiri sesuai form yang di sediakan sebelum melakukan diagnosa.

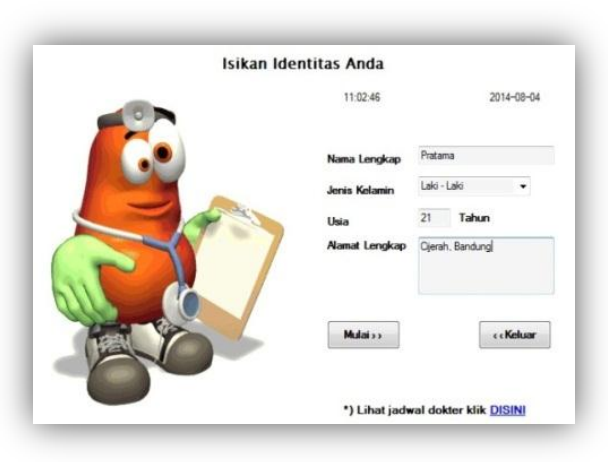

Gambar 11

Form Identitas Pasien

\section{Form Diagnosa}

Disini pasien di haruskan menjawab pertanyaan yang di sediakan oleh sistem sesuai apa yang anda rasakan.

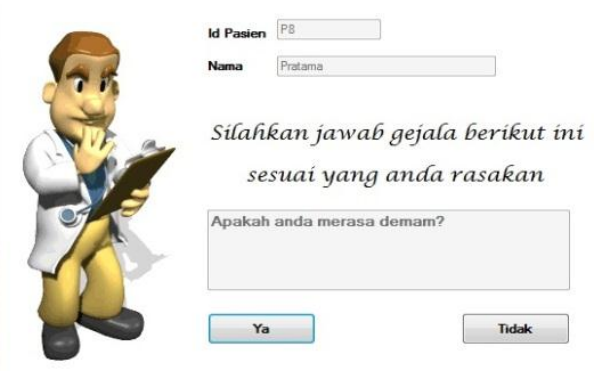

Gambar 12

Form Diagnosa

\section{Form Hasil Diagnosa}

Pasien akan mengetahui hasil dari diagnosa dari gejala-gejala awal yang di rasakan pasien.

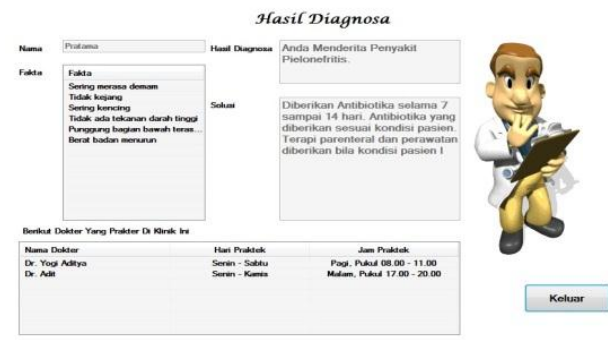

Gambar 13

Form Hasil Diagnosa

\section{PENUTUP}

\section{Kesimpulan}

Berdasarkan permasalahan yang di bangun pada Sistem Pakar untuk mendiagnosa penyakit ginjal dan saluran kemih ini, maka dapat diambil beberapa kesimpulan sebagai berikut:

1. Dengan adanya sistem pakar ini pasien dapat mengetahui gejala awal yang di alami pasien setelah melakukan diagnosa melalui sistem pakar ini.

2. Sistem telah mampu meminimalkan ketergantungan pasien terhadap pakar atau dokter dalam hal diagnosa dan solusi awal pengobatan penyakit ginjal dan saluran kemih.

3. Sistem pakar ini dapat memudahkan pakar dalam hal meminimalkan permasalahan akan keterbatasan jumlah pakar penyakit ginjal dan saluran kemih.

\section{Saran}

Saran-saran yang penulis kemukakan diaharapkan dapat meningkatka hasil yang lebih memuaskan dan bermanfaat bagi masyarakat khususnya parapengidap penyakir ginjal dan saluran kemih untuk mendiagnosa penyakit ginjal dan saluran kemih sejak awal. Berikut saran yang dapat di sampaikan:

1. Melakukan pembaharuan data apabila ditemukan kasus-kasus terbaru, sehingga masyarakat dapat memperoleh informasi lebih banyak lagi tentang penyakit ginjal dan saluran kemih.

2. Bila sistem akan di pakai di dalam suatu sistem di klinik atau rumah sakit, maka perlu penambahan entitas dan data untuk mendukung informasi yang dibutuhkan pada klinik atau rumah sakit tersebut.

\section{REFERENSI}

A. S, R., \& Salahuddin, M. (2011). Modul Pembelajaran Rekayasa Perangkat Lunak (Terstruktur dan Berorientasi Objek). Bandung: Penerbit Modula. 
A. S, R., \& Salahuddin, M. (2013).

Rekayasa Perangkat Lunak

Terstruktur dan Berorientasi

Objek. Bandung: Informatika.

Desiani, A., \& Arhami, M. (2006).

Konsep Kecerdasan Buatan.

Yogyakarta: Andi.

Joni, I., \& Raharjo, B. (2011).

Pemrograman $C$ dan

Implementasinya. Bandung:

Informatika.

Kroenke, D. (2006). Database Processing: Fundamentals, Design, and Implementation. Pearson Prentice Hall.

Martin, F. (2005). Panduan Singkat Tentang Bahasa Pemodelan Objek Standar (3 ed.). Yogyakarta: Andi.

Munawar. (2005). Pemodelan Visual Menggunakan UML. Yogyakarta: Graha Ilmu.

Priyanto, R. (2008). Langsung Bisa Visual Basic .Net. Yogyakarta: Andi Offset.

Ramdan, A. (2006). Pemrograman WEB Database PHP \& MySql. Jakarta: Elex Media Komputindo.

Romney, M., \& Steinbart, P. (2004). Sistem Informasi Akuntansi. Jakarta: Salemba Empat.

Sadeli, M. (2008). Pemrograman Database dengan Visual Basic .Net untuk Orang Awam. Palembang: Maxikom.

Wicaksono, Y. (2008). Membangun Bisnis Online dengan Mambo. Jakarta: Elex Media Komputindo.

Widodo, P. P., \& Herlawati. (2011). Menggunakan UML Informatika. Bandung: Andi. 